\title{
Paying for Watershed Services in Latin America: A Review of Current Initiatives
}

Authors:

Douglas Southgate, Sven Wunder

\section{Prepared by:}

Sustainable Agriculture and Natural Resource Management Collaborative Research Support Program (SANREM CRSP)

Office of International Research, Education, and Development (OIRED), Virginia Tech

E-mail: oired@vt.edu

On the Web: www.oired.vt.edu

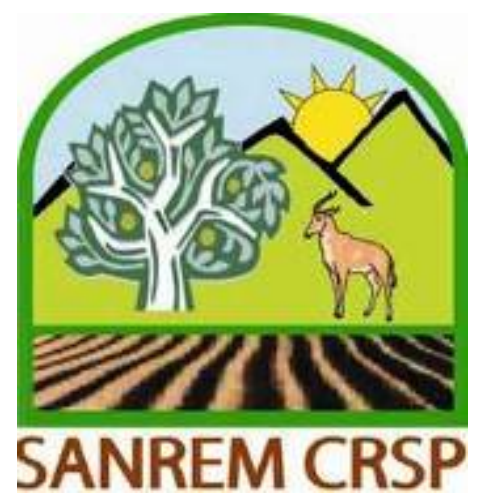




\section{July 19, 2007}

\section{Acknowledgments:}

Douglas Southgate*, Ohio State University, Columbus, Ohio southgate.1@osu.edu

Sven Wunder, Center for International Forestry Research, Belém, Brazil s.wunder@cgiar.org

*Dr. Southgate's participation in this project was supported in part by the USDA Cooperative State Research, Education, and Extension Service, Hatch project \#0208558. 


\section{Regional Review of Payments for Watershed Services in Latin America}

\section{Introduction}

In various settings, compensation is provided to resource users who volunteer to follow management guidelines. One example is the Conservation Reserve Program (CRP), in which U.S. farmers are paid for taking environmentally sensitive land out of production. Likewise, payments for environmental services (PES) are being harnessed for the sake of watershed conservation in Latin America and other developing regions.

Considerable enthusiasm has been expressed for PES from a conceptual point of view. For example, Simpson and Sedjo (1996) have highlighted the advantages of direct conservation payments over integrated conservation and development projects, which environmental groups and international development agencies favored from the late 1980s through the 1990s. The same advantages have been stressed in other writings (Ferraro, 2001; Ferraro and Kiss, 2002; Ferraro and Simpson, 2001). In a highly influential contribution to the literature, Rice et al. (2001) made the case that direct payments to forest dwellers are more effective than trying to promote sustainable, selective logging, which has been a feature of many integrated conservation and development projects.

Quite a lot has been written recently about PES as a tool for watershed conservation. The general approach is to compensate people in the upper reaches of drainage basins who refrain from land uses that exacerbate flooding, periodic water shortages, water quality problems and other problems at lower elevations (Landell-Mills and Porras, 2001, Pagiola, 2002). Full-fledged examples of this approach, however, remain few and far between (Robertson and Wunder, 2005).

This paper addresses the challenge of using PES to enhance hydrologic services in Latin America. To begin, the current state of implementation is described. We are able to identify just a few sites where each and every feature of PES is in place and many places where some but not all these features have been adopted. In the latter part of the paper, we examine why PES implementation remains incipient in Latin America, albeit farther along than in other parts of the developing world. Our analysis focuses on public policy, institutional factors, and political realities affecting PES in Latin America.

\section{Conservation Payments and Their Use in Latin America}

Although economists often have pointed out the merits of conservation payments that are direct and contractual, a precise and commonly accepted definition of PES has proven elusive. Attempting to provide such a definition, Wunder (2007) describes PES in terms of five characteristics.

1. There is a well-defined environmental service (e.g., specific changes in peak- or dry-season stream flow at the outlet of a watershed) or a suitable proxy for this service (e.g., hectares reforested).

2. There is at least one buyer of this service or proxy.

3. There is at least one seller as well. 
4. Transactions between buyer(s) and seller(s) are voluntary.

5. Payments are conditional on contracted environmental services or proxies for same actually being supplied.

Arrangements featuring all five of the preceding characteristics turn out to be rare in the Americas, even though the total number of PES or PES-like schemes (which satisfy most but not all of the five criteria) clearly exceeds numbers in Africa and Asia. One reason why conservation payments have been accepted a little more readily in Latin America appears to be that rural land tenure tends to be more secure in the region, in terms of de facto control over resources (be these private or communal properties). Without this control, users and owners of natural resources are in no position to be reliable suppliers of environmental services. ${ }^{1}$ Another reason is that commercializing rights to land use and land management practices is culturally and politically acceptable in much of the region. Major exceptions include parts of the Andes with large indigenous populations as well as Venezuela.

Among various stock-taking assessments of PES schemes, the most frequently cited is by the International Institute for Environment and Development (IIED) (LandellMills and Porras (2002). IIED is currently updating its survey of watershed-focused schemes. ${ }^{2}$ While such overviews provide a broad vision of existing initiatives, they cannot substitute for primary field evaluation. National-level PES appraisals have been carried out by the Center for International Forestry Research (CIFOR) and its partners for Bolivia (Robertson and Wunder, 2005), Colombia (Blanco et al., 2005), Venezuela (Blanco et al., 2006), and Vietnam (Wunder et al., 2005). A major finding of these appraisals is that many PES initiatives have not actually gotten off the ground. Some remained in the planning stage. ${ }^{3}$ Others were abandoned before implementation. ${ }^{4}$

Among the active projects identified in the IIED assessment, many have selected "PES-like" features yet still differ markedly in design and impacts from a complete PES scheme, as defined in this paper. For instance, various debt-for-nature swaps are included. Other assessments for the region include schemes in which local people are employed as forest rangers for protected areas, as opposed to being paid for an environmental service (Veen, 2007). There are also initiatives that function like a PES on the buyer's side, with service-users being charged, but without conditional payments to service-providers. This is the case with FONAG in Quito, Ecuador, which is the subject of one of the three case studies accompanying this paper, as well as payments by irrigators in Colombia's Cauca Valley.

The fact that these last two initiatives are frequently cited as standard cases in the PES underscores two lessons. One is the need to be cautious about what is labeled as PES. The other is the value of primary surveys, of the sort carried under CIFOR's auspices. An appendix to this paper contains a partial list of 90 Latin American projects with PES characteristics. Commentary follows about payments schemes undertaken for watershed conservation and other purposes in two parts of the region, the Andes and the

\footnotetext{
${ }^{1}$ This being said, many parts of Latin America are traversed by active agricultural frontiers. PES implementation is a considerable challenge in these settings, precisely because resource tenure is tenuous.

${ }^{2}$ The authors of this updated survey have kindly shared a preliminary draft with S. Wunder, cited in this paper as "Ina Porras and Nanette Neves, personal communication, September 2007.

${ }^{3}$ One of these is the national CIF watershed conservation program in Colombia.

${ }^{4}$ The Bermejo River watershed protection scheme in Bolivia is a case in point.
} 
Amazon, with which this paper's authors are familiar. Broader geographic coverage is accomplished by including a case study of Mexico's program for environmental-service payments and a box-description of the pioneer national PES scheme in Costa Rica.

The Andes. Due to increasing water scarcity and upstream forest loss, there is a high potential for watershed PES in many parts of the Andes, where mountainous topography coincides in many places with large numbers of water consumers. Nevertheless, receptiveness towards conservation payments varies. While some places are fairly open to market-based incentives for water management, others are not. Resistance sometimes has to do with a history of resource usurpation. In addition, some people cannot reconcile the fact that water satisfies basic human needs with the reality that hydrologic resources are growing scarcer and hence more marketable - or even that channeling water from its sources to the places where it is consumed is not free, and therefore must be financed either by consumers or others. In societies with a strong indigenous culture (e.g., the Bolivian highlands), PES development tends to lag. The same holds for large, closed economies, such as Venezuela.

Incentives are strong in Bolivia to protect watersheds as well as the amenity resources harnessed for ecotourism. However, skepticism is widespread toward the "neoliberal" approach to natural resource management, generally, and PES, specifically. Related to this are suspicions of disguised privatization of public-access resources, including water. Furthermore, key preconditions for PES, such as secure land tenure, are still lacking in many places. As a result, most conservation initiatives are properly categorized as traditional projects. Among the few genuine PES pioneers in Bolivia is a small scheme administered by Fundación Natura, a national NGO, in the buffer zone of Amboró National Park, where irrigator and biodiversity payments are pooled to finance conservation (Asquith et al., forthcoming). Opportunities to use the same approach are more promising in the Andean foothills and the transition to Bolivia's lowlands (Media Luna), where there is less ideological resistance to economic instruments and where irrigated, commercial agriculture and urban water consumers comprise potential buyers. Various municipalities in Tarija and Santa Cruz are also experimenting with PES-like watershed schemes (Robertson and Wunder, 2005).

In terms of water scarcity, management benefits, and numbers of water consumers, the potential for watershed PES is as large in Peru as elsewhere in the Andes. But so far, experimentation with PES has been less in Peru than in Bolivia. No projects for carbon sequestration appear to be running, although some are under preparation. As for watershed schemes, the most serious efforts have been in Alto Mayo-Moyobamba, San Martín department, and in the Jequelepeque and Piura watersheds, where German GTZ and CONDESAN have been working together in the Andean Watersheds Project (Veen, 2007). While negotiation processes have advanced noticeably, a primary obstacle has been to transform willingness-to-pay on the part of potential service buyers into actual monetary flows (A. Moreno-Díaz, personal communication, January 2007).

At present, no South American nation has a richer PES portfolio than Ecuador, where ideological hostility to conservation payments is less than in Bolivia and Peru. Two pioneer schemes that fit the five-point PES definition completely have been running for years. One is the PROFAFOR carbon sequestration program, which has been operating for a decade (Albán and Argüello, 2002). The other is the Pimampiro municipal watershed scheme, which is the subject of one of our case studies. These 
forerunners have inspired a new generation of local, self-organized PES schemes, including a municipal watershed project in Celica (Loja Province). Another type of scheme draws on water funds to which customers contribute to finance watershed conservation. However, these funds, which have been established in Quito, Cuenca, and El Angel, finance conservation projects rather than being used to compensate private providers of environmental services.

Colombia is probably the most advanced Latin American country in terms of creating innovative mechanisms for the financing of conservation. But while charging users of environmental services has become widespread in the country, compensating service-providers on the ground is less advanced than in Ecuador. Most monies go to traditional project activities, studies, and administration. A national program for the protection of critical watersheds, inspired in part by a similar program in Costa Rica (see Box), was designed a few years ago. However, the CIF de Conservación was never implemented due to lack of funds. The Familias Guardabosques is another national payments scheme, but has no real environmental conditionality and therefore reduces to a program for eradicating coca bushes (Blanco et al., 2005). One full-fledged PES scheme is a silvo-pastoral initiative for biodiversity and carbon enrichment financed by GEF (Pagiola 2004), which one of the project partners (CIPAV) currently plans to extend to watershed management. Watershed experiences include a water-fund irrigator scheme in the Cauca Valley, which does not make use of direct compensation for service-providers. Significant PES potential seems to exist at the provincial (corporación) level, where the bulk of environmental finance is administered (Blanco et al., 2005).

No genuine PES or PES-like schemes exist at present in Venezuela. However, a hitherto under-utilized national program (Subsidio Conservacionista) constitutes a potential legal framework for the approach. Furthermore, increasing demands for environmental services, especially for watershed protection, create a large potential for (and local-level interest in) PES. In some of the six sites examined during a recent field assessment (Blanco et al., 2006), conservation payments seemed feasible if the willingness-to-pay of service users could be captured. In fact, due to a high degree of urbanization in Venezuela, the ratio of potential providers (i.e., upstream landowners) to potential beneficiaries (including urban consumers of water and hydropower as well as irrigated agriculture) is low, which favors PES. In one part of the Andes - the Pereña and La Jabonosa watersheds, which are the source of drinking water for the western part of Táchira state - consumers are already paying a minor management fee, equal to 0.5 percent of their water bills, and the public water utility company is now planning to make compensation payments on a trial basis (Blanco et al., 2006). Unlike in Ecuador, though, true PES in this and other cases may only be achieved with close participation of the central state.

In summary, PES development in the Andean region is uneven, with Ecuador and Colombia more advanced than Bolivia, Peru, and Venezuela. Some of this variation traces to political-ideological factors. Watershed services clearly dominate other services and demand for the former is on the rise. Other than some trial initiatives in Colombia, all existing schemes are self-organized by buyers, sellers, and intermediaries, with little involvement by the central state. Basically all schemes are bilaterally negotiated deals not quite markets in which environmental services are bought and sold continuously. 
The Amazon and Brazil. Fed mainly by major watercourses flowing out of the Andes, the Amazon is the world's most voluminous river, with average discharge at its mouth exceeding normal flow from the Mississippi River into the Gulf of Mexico by an order of magnitude. Furthermore, the largest continuous rainforest on Earth lies in and around the river's drainage basin. This ecosystem performs multiple environmental functions, some of global significance.

PES activity has occurred in the Amazon. For instance, payments have been collected from tourism operators in Peru's Madre de Dios region to finance the conservation of scenic vistas (Veen, 2007). A similar scheme exists in Bolivia's Madidi National Park, which is one of the world's most biodiverse protected areas (Robertson and Wunder, 2005). However, the specific mechanics of these initiatives differ from those of a pure PES (Ferraro and Simpson, 2005). Much debated has been a trial of conservation concessions in an extremely remote and sparsely populated part of Guyana, undertaken by Conservation International (Hardner and Rice, 2002).

With broad stretches of cheap land available for tree-regeneration, the Amazon and adjacent territories are attractive settings for carbon-sequestration initiatives. Illustrative in this regard is a project underwritten by Peugeot, the French auto-maker, to establish forests on 5,000 hectares of degraded pastures in Mato Grosso state. Another Brazilian example is the Ilha de Bananal "social carbon" initiative, designed to arrest deforestation in the Cerrado transition zone (May et al., 2004). Particularly well known is Bolivia's Noel Kempff Mercado Climate Action Project, in which a national park with elevated biodiversity as well as huge volumes of standing timber has been extended by 634,000 hectares to put a brake on logging and agricultural colonization (Asquith et al., 2002; May et al., 2004; Robertson and Wunder, 2005). Additional PES activity of this sort is to be expected, given that interest is growing in arresting deforestation so as to curb carbon emissions and to safeguard species-rich ecosystems.

However, there is much less interest in the Amazon in PES with a hydrologic purpose. One economic reason for this is that water is abundant in the region. Moreover, improved resource management at higher elevations has very little effect on the quantity or quality of water downstream. Even the impacts of conservation on peak run-off during or right after storms tend to be small at the scale of a large drainage basin (Chomitz and Kumari, 1998).

Paired with abundant supplies of water in the Amazon Basin are limited demands for the resource. Outside of a few large cities, such as Iquitos, Peru and Manaus and Belém in Brazil, just a few million people live in the continent-sized area that would benefit (modestly) from watershed conservation. Hydroelectric projects, some of major dimensions, have been developed in the Brazilian Amazon. But the flat topography, which results in extremely large reservoirs, reduces the impacts of sedimentation $i$ and the benefits of arresting sedimentation are probably not significant.

Some hydrologic services are potentially important in the Amazon. For example, it has been hypothesized that continued deforestation in the region could have a noticeable effect on climate in other parts of Brazil and perhaps even in the wider region. However, these effects have not been demonstrated conclusively enough to trigger willingness-to-pay for forest protection.

Finally, there are instances in which economic interests in the region are harmed by environmental deterioration, although institutional conditions impede PES. A case in 
point is the harm done to freshwater fisheries because of logging and deforestation. While scientists have presented convincing evidence of this harm, little if anything is done about the problem. One reason is that small fishermen, who stand to capture many of the gains from ecosystem protection, are socially minor and poorly organized, which reduces the political influence they might exert to establish conservation payments or some other environmental measure. Also, fisheries are an open-access resource, which means that free-riding among the beneficiaries of conservation tends to interfere with the effectiveness of a conservation tool like PES - as is explained later in this paper.

The Brazilian government has launched the Proambiente program, in which payments are used to promote environmental sustainability in the Amazon. Groups of farmers are contracting to follow land-use plans that feature restrictions (e.g. no clearcutting or burning), which augment environmental services, including watershed protection in principle. In return, they receive payments from the central government. The program has had a long preparation phase and was led by movements representing the rural poor, rather than being created to satisfy demands for environmental services. Certain pilot areas in the Amazon were selected for application, and in 2006 the first set of payments were made. However, the program depends entirely on the general government budget - as opposed to an earmarked tax (such as the fuel tax in Costa Rica see Box) or contributions from parties outside of government who value environmental services (e.g., buyers of carbon credits). For this reason, Proambiente's financial outlook is not encouraging. This highlights an important advantage of PES, which is to organize service-buyers and other advocates for conservation with some sort of political presence.

In other parts of Brazil, carbon initiatives have been implemented. For instance, the Plantar project, financed by the World Bank's Prototype Carbon Fund, aims to provide economic incentives for sustainable wood supplies for pig iron production in Minas Gerais state (May et al., 2004). Several cities in the southern part of the country have shown interest in PES or PES-like schemes for the sake of watershed conservation. One of these is the "Ecological Value Added Tax (VAT)," which was implemented first in Paraná and later in other states (Grieg-Gran, 2000; May et al., 2002).

This arrangement comprises a departure from normal practice, in which VAT revenues are allocated according to levels of economic activity. Since local jurisdictions with extensive forests and other natural vegetation normally receive lower revenues, conservation is discouraged. In contrast, the Ecological VAT takes into account both the size and quality of natural assets, with particular emphasis given to watershed and recreational benefits that are measured by environmental indices. Clearly, the alternative arrangement adds to conservation funding and is also conditional. However, it mainly serves to alter the allocation of government monies to projects undertaken by the public sector, with very little compensation provided to private-sector providers of public services. For this reason, the Ecological VAT is properly classified as borderline-PES.

\section{Analyzing the Challenge of PES Implementation}

It is a considerable leap from pointing out the general advantages of direct conservation payments to full implementation of PES, which involves the recruitment of voluntary participants on both the demand side and the supply side of a market for a welldefined environmental service - a set-up, furthermore, in which everyone involved understands that payments are conditional. Little wonder, then, that discussions of this 
alternative in Latin America revolved for many years around the experience of Pimampiro, Ecuador. Thanks to outside support, this small, Andean community and its watershed were just about the only setting in the region where all five elements of PES had been put in place (Echavarría et al., 2002; Wunder and Albán, forthcoming).

As documented in the preceding section, conservation payments are used somewhat in the Andes and sparingly in Brazil. Elsewhere in Latin America, a program of national scope exists in Mexico (see Case Study 3). Also, PES implementation is far advanced in Costa Rica (see Box) and other parts of Central America. In contrast, there is little evidence of this approach so far in other places, including in Chile. ${ }^{5}$ This is surprising not only because the country depends heavily on managing water resources well, but also because its tradition of strong property rights and pro-market economic policies is harmonic with PES.

To understand why conservation payments are not used more widely in Latin America, we adapt from a general framework for distinguishing among and analyzing basic obstacles to economic development, broadly defined (Hausmann, Rodrik, and Velasco, 2005, cited in Rodrik, 2006). As represented in Figure 1's flow-chart, the first diagnostic step involves evaluating two fundamental reasons for the limited use of PES. One of these is low benefits. The other reason is high costs.

\section{Figure 1: Diagnosing the Challenge of PES Implementation}

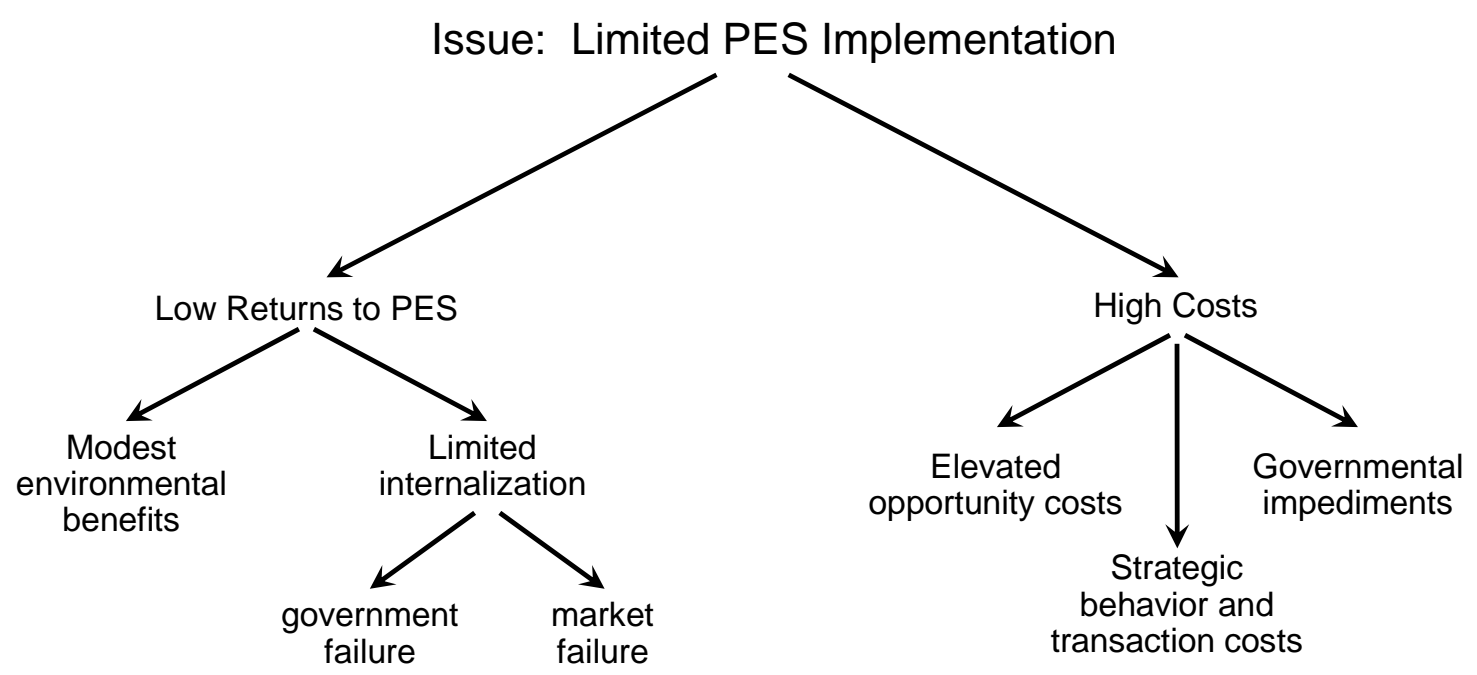

As also shown in Figure 1, the returns to PES can be modest because environmental benefits are limited (perhaps for geographical reasons), these benefits are difficult for economic agents to internalize (because of government or market failure), or perhaps both. Likewise, the costs of PES implementation are influenced by various factors. One of these, which obviously influences compensation levels, is the opportunity cost of resources that payment-recipients are asked to give up, at least for a while, so that

\footnotetext{
${ }^{5}$ At the Ecosystem Services Conference held in Valdivia, Chile in November 2006, considerable interest was expressed in PES, although there were no watershed-level applications of the approach were presented. One possible reason for this is that foreign donors and development agencies play less of a role in the country than in other parts of Latin America.
} 
environmental services can be produced instead. Investigation of the cost side of PES implementation also involves accounting for strategic behavior and transaction costs, both of which tend to proliferate as numbers of resource users and stakeholders rise, as well as looking at ways that the public sector makes PES implementation more difficult, not less so.

We now consider, in order, the benefits and costs of PES, as is needed to explain current adoption of this approach in Latin America as well as the future prospects for PES in the region.

Modest Environmental Benefits. For nearly as long as watershed conservation initiatives have targeted small farmers and others in the upper reaches of drainage basins, who are the main recipients of PES, doubts have been expressed about the environmental benefits of these initiatives. One criticism, made by Hamilton and King (1983) and others, is that natural (or background) variability in environmental parameters often outweighs the impacts that upper-watershed inhabitants have on the environment. Further complicating the issue is that the scientific uncertainty over the relationships between land management and environmental impacts is often considerable. The displacement and transport of sediments comprise a case in point. Where land formations are of recent geological origins, with steep slopes and poorly consolidated soils, natural erosion in drainageways and stream channels is often substantial, particular after heavy, tropical downpours. Expensive to control and difficult to estimate, this natural erosion can easily dwarf the volumes of soil lost from small farms. One area where this is the case is the mountainous watershed upstream from Ecuador's largest hydroelectric facility, in the southern part of the country (Southgate and Macke, 1989).

Likewise, water yield is an environmental service that, as a rule, is influenced more by precipitation and other natural conditions on an annual basis than by the number of trees that small farmers and other PES recipients may or may not save or plant. Once again, scientific uncertainty on cause and effect relationships is considerable. For example, newly planted trees often consume more water than other vegetation, which can actually diminish the availability of hydrologic resources for other uses. On the other hand, a maturing forest improves soil function, such as infiltration, which can enhance water yield during the dry season and diminish runoff during and right after downpours. Less uncertain are the hydrologic benefits of conserving cloud forests, since the loss of this habitat can reduce fog-capture (or horizontal precipitation) noticeably. This impact has been demonstrated at selected sites in Central America and the Andes, although significant scientific uncertainties remain over these relationships. Moreover, the lack of reliable methods for rapid assessment means that determining the hydrologic benefits of preserving cloud forests is often a challenge - at times, more expensive than payments to upstream farmers required to preserve that habitat, as demonstrated in a Bolivian watershed (Asquith et al., forthcoming).

Hamilton and King (1983) also observe that upper-watershed inhabitants are not always the most important human agents of environmental change. To the contrary, road-building, sand and gravel mining, and other large-scale activities, which usually are not the target of PES schemes, are frequently more important causes of watershed deterioration than small-scale farming. The aforementioned hydroelectric watershed in southern Ecuador is illustrative in this regard (Southgate and Macke, 1989). 
To summarize, the expected environmental benefits of direct conservation payments to people in the upper reaches of drainage basins may be obscured by natural environmental variability, spotty scientific evidence about the hydrologic consequences of land-use change, risks of non-compliance on the part of providers, and the impacts of human activities not normally targeted by PES initiatives. Alone, these obstacles may not jeopardize PES implementation. That is, service-users may be willing to address some (as opposed to all) problems in a watershed and to accept that the probability of success is less than 100 percent. However, these obstacles can be very debilitating when combined with appropriation problems, to which we now turn.

Limited Internalization. Even if the environmental benefits of PES are potentially sizable, the returns to a payments scheme may be reduced, because market failure or government failure cause benefits not to be internalized - or, to use terms generally regarded as interchangeable, captured or appropriated.

Market failure can diminish the internalized returns of PES in various ways. For instance, safeguarding ecosystems in upper watersheds may create multiple environmental services, only some of which interest buyers in a PES scheme. A representative case would be for the hydrologic impacts of habitat conservation to be valued and paid for, but not the effects on biodiversity or carbon sequestration. Potential buyers of the latter services may choose not to offer payments due to lack of information, high transaction costs, or incentives to free-ride on the party or parties paying for watershed conservation. If so, non-watershed values comprise externalities. Too little money may be collected and conservation payments may achieve a sub-optimal level of ecosystem conservation.

Market failure can also arise in a setting where conservation of a single area of hydrologic importance improves water supplies in two or more downstream communities. One or more of these communities might free-ride, counting on the others to finance the protection of the water source on their own. In the face of this strategic behavior, which causes some watershed values not to be captured, overall funding may be insufficient to achieve the desired hydrologic services. Conceivably, communities considering paying for environmental services might conclude that doing so is not worthwhile, particularly if there are no institutional arrangements for securing the collective action necessary to compel payment from all beneficiaries.

Aside from market failure, government failure can diminish the appropriation of environmental benefits, thereby making PES less attractive. This is certainly a possibility where potable water is sold for less than its cost - a policy that used to be widespread in Latin America and which continues to be applied in a number of settings.

Consider the impacts of conservation payments if the revenues that a municipal water company collects from its customers in the absence of PES are less than the combined expenses of amortizing, operating, and maintaining its pipe network, pumping stations, and other infrastructure. The unrecovered portion of these expenses is represented in Figure 2 by the rectangular area, $(C-P) \times Q$, where $C$ represents the average amortization, operation, and maintenance cost of delivering water $(\mathrm{Q})$ to the company's customers and $\mathrm{P}$ is the subsidized price paid by these consumers. The demand curve's negative slope indicates that consumption goes down as the price goes up, ceteris paribus. The average-cost curve also slopes downward, which reflects the fact that delivering water throughout a single city is a natural monopoly. 


\section{Figure 2: PES, Price Subsidies, and Natural Monopoly}

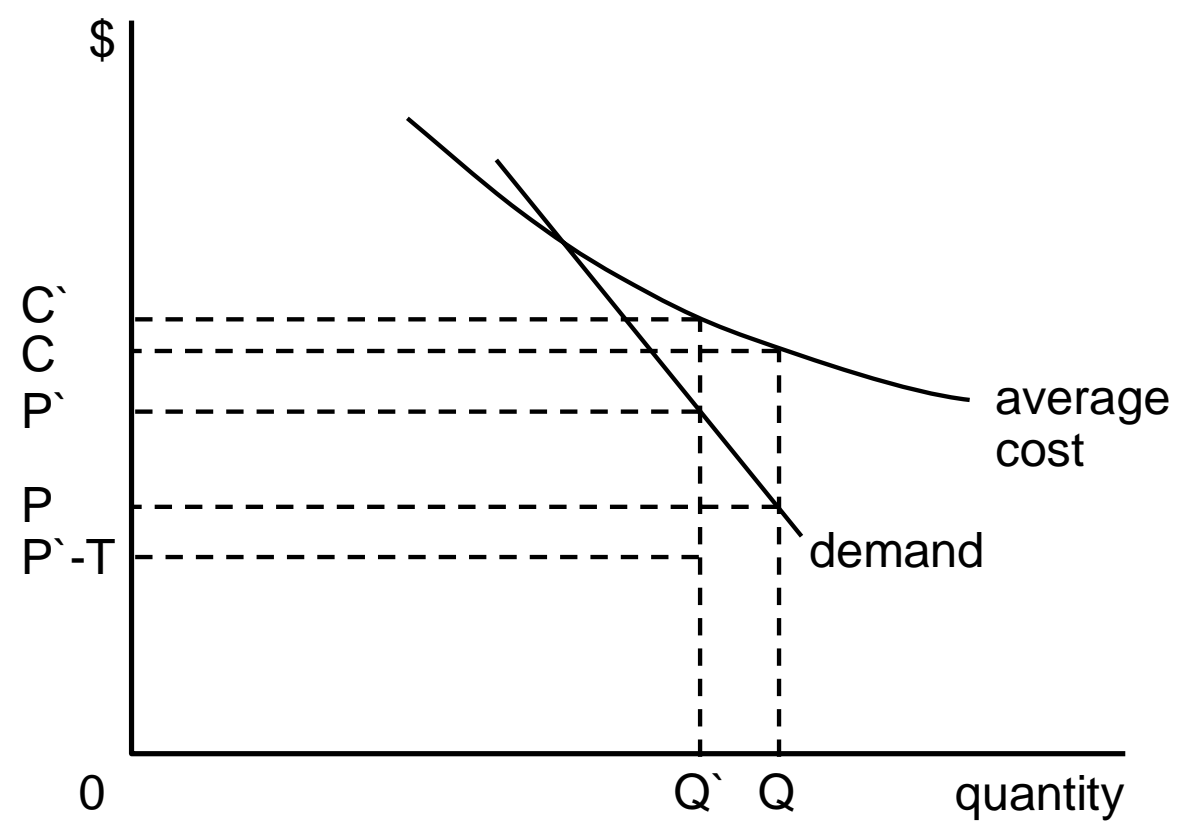

Suppose a conservation payment is instituted, equal to $\mathrm{T}$ on each unit of water sold. As far as consumers are concerned, the price of water has risen, which causes them to cut back on purchases. At the higher price, P' (which includes T), consumption is lower, Q'. Significantly, the unrecovered portion of amortization, operation, and maintenance costs goes up. One reason for this is that, provided demand is not perfectly inelastic (as would be indicated by a perfectly vertical demand curve), the revenue received by the supplying company for each unit of water it sells - $\mathrm{P}$ ' minus the conservation payment - is lower than per-unit revenue in the absence of PES, which is $\mathrm{P}$. At the same time, average cost goes up, to C', because supplying water is a natural monopoly. Between these two impacts, the unrecovered segment of amortization, operation, and maintenance costs with PES - (C' - [P' - T]) x Q' - almost certainly exceeds the unrecovered segment of these costs without PES - $(\mathrm{C}-\mathrm{P}) \times \mathrm{Q}$.

The economic circumstances depicted in Figure 2 elucidate the opposition to PES that can arise within a municipal water company. If water consumption is negatively related to price and if supplying water is a natural monopoly, increasing its price and locking in a portion of revenues for environmental protection, which is exactly what conservation payments are supposed to accomplish, can add to the challenge of meeting other costs, which as already mentioned are not fully recovered in many places even without PES. This problem helps to explain why some professional staffers in the municipal water company of Quito, Ecuador have been less than enthusiastic about

\footnotetext{
${ }^{6}$ With natural monopoly, efficiency requires that price be less than average cost. That is, the efficient price equals marginal cost, which is less than average cost as long as the latter is declining. However, water subsidies in Latin America rarely if ever are driven by a desire to achieve efficiency. Rather, the main motivation is simply to benefit consuming households, especially those with political influence.
} 
including environmental payments in customers' bills and dedicating these payments to watershed conservation and related activities (see Case Study 2). For these opponents, PES complicates the task of paying for amortization and operations and maintenance.

Elevated Opportunity Costs. Even if environmental benefits are both sizable and readily appropriated, a conservation initiative may fail because of high costs. One factor that can drive up costs is the need to protect critical areas against damage by third parties, by putting in a fence (to keep cattle out) or a fire break for instance.

Uniquely, PES costs include payments made to households that supply environmental services, payments which are influenced by farming practices and earnings and other elements of household-level survival strategies. Some small-scale farmers in Latin America may use land more productively than operators of large-scale haciendas, which causes them to demand more compensation per hectare before taking part of their land out of production or agreeing not to deforest part or all of their holdings. In contrast, some subsistence producers may settle for lower payments, if the additional cash relaxes the financial constraint on seeking alternative off-farm employment.

Household-level risk, which is a major concern in rural areas throughout the developing world, has important consequences for PES. One possibility applies to people who engage solely in farming. For them, receiving a reliable payment makes overall income, which otherwise consists entirely of the varying returns to agriculture, less variable. Depending on how risk-averse they are, these people may accept modest payments in return for adopting conservation measures.

In contrast, the appeal of PES to the many households in the Latin American countryside that have diversified their sources of income may be more qualified. In El Salvador, for example, much of the rural population has risen out of poverty by starting micro-enterprises or finding non-agricultural work. Nevertheless, they do not abandon farming entirely, mainly because growing some of one's own food is a way to deal with the downside risks of off-farm employment (Rodríguez-Meza, Southgate, and GonzálezVega, 2004; González-Vega et al., 2004). Clearly, any payments directed toward such households would need to reflect the de facto insurance value of resources that provide nourishment when off-farm employment and earnings ebb, particularly if paymentrecipients pay a heavy penalty for abrogating PES contracts.

An empirical study carried out in the vicinity of Quito, Ecuador provides evidence that the receptiveness of rural people to conservation payments is influenced by their sources of income, which feature varying levels of risk. ${ }^{7}$ The study site was a rural community, Cangahua, located in the same Andean drainage basin as the capital city. Moreover, Cangahua is representative of the places where PES are being implemented or proposed in order to safeguard water supplies.

Approximately, 200 rural households in Cangahua were surveyed in early 2004, with agricultural, economic, demographic, and other data being collected. The questionnaire included a contingent-valuation (CV) question, which was designed to elicit the minimum payments that households would demand in return for taking erosionprone land out of production for five years. Among the findings of econometric analysis of responses to this question was that respondents engaged primarily in subsistence farming are willing to accept relatively modest payments, because PES represent an

\footnotetext{
${ }^{7}$ This research was supported financially by the Sustainable Agriculture and Natural Resource Management Cooperative Research Support Program (SANREM-CRSP).
} 
attractive alternative to the modest and varying returns from subsistence agriculture. In contrast, the compensation demanded by households that have succeeded in diversifying their income sources is considerably higher, evidently because such households place great value on their access to resources that can be harnessed in a pinch for subsistence food production (Southgate, Haab, and Rodríguez, 2005).

To determine PES compensation levels, the standard practice has been to take a somewhat narrow view of the opportunity cost of resources that payment-recipients are currently using and are being asked to give up (for a while). That is, opportunity cost is defined and measured, simply, as the expected market value of agricultural and other output that a payment-recipient must sacrifice. Research of the sort undertaken in Cangahua raises the possibility that this approach yields estimates that are too high in the case of subsistence farmers. At the same time, narrow calculations of opportunity costs can understate the minimum payment demanded by someone with diversified earnings. This is because such calculations do not take into account how households deal with risk, such as maintaining the option of using land for subsistence production during hard times.

Strategic Behavior and Transaction Costs. Aside from reflecting all values that PES recipients place on land they are being asked to take out of production or manage differently, payments can be driven up by strategic behavior on their part, transaction costs, or both. Strategic behavior can arise whenever a fundamental efficiency-criterion for PES is satisfied: the downstream value of watershed services provided by multiple suppliers exceeds the combined payments required to produce these services. Under these circumstances, an individual supplier might engage in holding out, in the hope of capturing more of the net benefits of watershed services - that is, the difference between downstream benefits and upstream costs (including conservation payments). If there are several hold-outs, then the entire deal between upstream providers and downstream beneficiaries of watershed services might collapse.

Strategic behavior of this kind can be contained. One option is to implement the sort of bidding procedure proposed by economist William Vickery, a Nobel laureate. The unique feature of a Vickery auction is that winning bidders do not pay or receive the price they named, but instead the amount offered by competitors whom they have edged out (Kagel, 1995). In the case of watershed PES, people whose offers to conserve land have been accepted receive compensation a little above what they have proposed. This arrangement discourages exaggerated bids, as hold-outs submit, since the main consequence of exaggeration is to increase the payment received by someone else.

The existence of mechanisms such as Vickery auctions means that strategic behavior need not interfere with PES adoption. If direct payments are truly a good way to finance watershed management, because conservation costs are exceeded by downstream benefits, then the problem of hold-outs can be contained. By the same token, free-riding, which interferes with the internalization of environmental values (see above), can be kept in check by designing markets properly.

Also difficult to contain in many settings are transaction costs, which relate to negotiating contracts with the providers of environmental services, monitoring compliance with these contracts, and related tasks. In Pimampiro (Case Study 1), payments from water consumers, who benefit from watershed conservation, are sufficient to finance all compensation received by providers of environmental services, which 
varies from US\$6 to US\$12 per hectare per annum, as well as recurring transaction costs, which are estimated to be US\$1.57 per hectare per annum (Wunder and Albán, forthcoming). However, a grant of US\$37,000 from foreign donors was needed to cover start-up expenditures on background studies, negotiations, and development of a contracting and monitoring system (CEDERENA, 2002).

Transaction costs, start-up as well as recurring, cannot be avoided if the criterion of conditionality is to be satisfied and can be a major barrier to extending the sort of scheme that Pimampiro has pioneered to other places, within and beyond Ecuador.

Governmental Impediments. One reason why transaction costs are sizable, especially for small communities, is that increasing returns to scale ${ }^{8}$ are a fundamental characteristic of monitoring, which requires remote-sensing capacity and trained personnel for tracking and ground-truthing resource use by payment-recipients. Pimampiro has been able to attract external grants to cover the initial investment in technological capacity and human resources because its PES program has been experimental and path-breaking. If the program is to be replicated elsewhere without such grants, however, one of two things must happen. One option is to change technology in ways that reduce the costs of monitoring at a small scale. The other option, which makes particular sense if increasing returns to scale continue to be a feature of monitoring, is for national governments to provide monitoring and related support, thereby allowing scale economies to be exploited. The idea here is not for the central authority to provide subsidies. Instead, a national agency, which would purchase machinery and software and would hire qualified personnel, would offer its services at a price reflecting its costs, which would be lower than expenses facing a small jurisdiction trying to monitor PES deals on its own.

Lamentably, the governments of Ecuador and other Latin American nations are at present unprepared to make this contribution. One reason for this is revealed by an analysis of Ecuadorian laws relating to PES. Virtually all these legal arrangements focus on the central government's ownership of biodiversity and other resources, obviously anticipating sizable international payments for access to these environmental assets. In contrast, existing laws and regulations are silent on the support that the national state could provide to local PES schemes (Corral and Rodríguez, 2006). As a result, the use of PES in watershed conservation remains excessively expensive, and therefore not resorted to as often as it can or should be.

There is an irony here, given the interest that the national state has expressed in biodiversity conservation. Many of the habitats protected by local watershed initiatives, such as Pimampiro's, are species-rich. The central state's failure to support such initiatives by bringing down transaction costs actually diminishes Ecuador's diverse living resources.

\section{Summary and Conclusions}

Accurate appraisal of PES implementation requires detailed observation at the field level, mainly to distinguish between schemes with all five characteristics of this approach and those with some though not all these characteristics. Drawing on a handful

\footnotetext{
${ }^{8}$ Where returns to scale are increasing, as is the case both with monitoring compliance with PES agreements and with potable-water supply, then per-unit cost declines as the activity in question increases, exactly as is indicated by the downward-sloping average cost curve in Figure 2.
} 
of assessments in which appraisal of this sort has been carried out as well as our own knowledge of selected nations, we conclude that the PES implementation in Latin America is similar to the state of implementation elsewhere in the developing world. That is, most initiatives currently in operation are "PES-like," not full-fledged examples of the approach. Of the majority, many schemes have failed to cultivate buyers of environmental services, relying instead on contributions from external donors. Others do not feature conditionality, with implementing agencies shying away from the businesslike practice of paying only when services are rendered. This reluctance has to do in part with concerns about disrupting relationships with poor farmers, which suggests that PES development and the alleviation of rural poverty may not be entirely harmonious.

Our report on PES in the Andes, the Amazon, and other parts of the Western Hemisphere as well as our analysis of challenges facing this approach suggest that various things can be done to increase the use of conservation payments. Greater scientific understanding of key hydrologic linkages (e.g., sediment displacement due to natural and human forces) would help. So would the counteraction of strategic behavior, through the use of innovative bidding procedures as well as the development of institutional arrangements conducive to collective action. Government policies, such as selling water below its cost, need to be reformed. At the same time, the public sector needs to help reduce scale-dependent transaction costs, which are especially burdensome for small communities and which counter the capture of society-wide benefits (e.g., biodiversity protection) created by watershed protection at the local level.

Beyond coming to terms with specific tasks such as these, one must bear in mind broader reasons why there is often a gap between what PES theorists have imagined in scientific articles and the reality of PES on the ground. One of these is that Latin Americans traditionally have made use of the natural environment for free - logging, mining, and expanding the agricultural frontier pretty much as they pleased. In light of this history, actually paying for environmental services, in response to mounting resource scarcity, represents a major change.

In addition, inertia sometimes can constitute a hindrance to the adoption of innovative policies, such as PES. The benefits of this new approach have yet to be conclusively demonstrated, in part because experience with conservation payments is still limited. Also, PES implementation is held back in many places because of mistrust by key stakeholders. For example, service-providers - most notably, small, indigenous farmers - fear that PES represent a first step toward permanent expropriation of their resources. At the same time, service-users might suspect that they are or will be the victims of "environmental blackmail.” Intermediaries, including NGOs and civil-society elements, sometimes have the confidence of stakeholders needed to overcome "perceptional obstacles" such as these. The presence of such "fair brokers" between users and providers of environmental services often catalyzes early PES initiatives, which can in turn lead to scaled-up programs such as the Costa Rican PSA or the Mexican PSA-H. Aside from being trustworthy, these intermediaries also need to be willing to invest the time and effort required for effective negotiations.

As such negotiations are pursued, there is no reason to insist always on one-sizefits-all when applying economic incentives in environmental management, with conditionality and all other features of PES in place everywhere. But while customizing schemes to local conditions may be entirely sensible, we are convinced that payment- 
initiatives in a number of settings would be more effective if these adhered more closely to all five PES principles. For example, when service users do not pay, it is almost impossible to make a PES scheme sustainable, since external sources of support are bound to decline sooner or later. In addition, when there is no strong conditionality, service delivery is compromised in most cases. Following a complete set of guiding PES principles, then, is not just a question of academic grace. Instead, doing so directly affects the functionality of conservation payments. 


\section{CASE STUDY 1 PIMAMPIRO, ECUADOR}

Located in the Andes of northern Ecuador, the municipality of Pimampiro draws most of the water for its 13,000 inhabitants from the 630-hectare Palahurco watershed. Responding to water shortages and inspired by Costa Rica's PSA program (see Box), the town has used PES to finance the protection and regeneration of natural forests and páramos (alpine grasslands) since 2000. Adoption of this approach was made possible by an external grant of US\$37,000 to CEDERENA, a local NGO. This grant was used to cover start-up expenses, including those related to background studies, negotiations, and development of a contracting and monitoring system (CEDERENA, 2002).

Recipients of payments all belong to the Nueva América Cooperative. In places more than 3,000 meters above sea level within the watershed, these members had increased livestock pastures and potato fields gradually over time, in addition to occasionally extracting timber. Although no hydrologic studies were carried out before the payments scheme was adopted, the municipal government of Pimampiro reckoned that these activities threatened the quality and seasonal stability of water supplies. Accordingly, PES enrollment for five years was offered to all owners of high-altitude lands, with contracts renewed in early 2006.

Since the program's inception, monthly payments have ranged from US\$0.50 per hectare for previously cultivated land that has been allowed to revert to natural vegetation to US\$1.00 per hectare for pristine forests and páramo (Echavarría et al., 2002). Added to this compensation for landowners have been recurring transaction costs for the water company - related to monitoring, administration, and related tasks. These costs amount to US\$1.57 per hectare per annum (Wunder and Albán, forthcoming).

Compensation paid to landowners is covered fully by the 1,350 households and businesses in Pimampiro with water meters, which pay a 20-percent surcharge on their monthly bills. Non-paying water users, including irrigators, can be considered free riders. A municipal account with a balance of about US\$15,000 comprises a financial guarantee for payments to members of the Nueva América Cooperative who fulfill their contractual obligations (Wunder and Albán, forthcoming).

Pimampiro's program contains the critical feature of PES, which is that payments are conditional. Initially, CEDERENA was responsible for monitoring selected plots of land every three months. This task subsequently passed to the municipal government, which occasionally has lacked the necessary workforce. However, conditionality has been maintained by sanctioning payment-recipients who do not honor land-use agreements. From 2002 through 2004, payments were cut off to several households that were found to be in violation, although some were allowed to reenroll later. Currently, 19 contracts are in effect, representing four-fifths of the Nueva América membership and covering 550 hectares.

Although a few members of the cooperative do not participate in the program, conservation payments that are voluntary and conditional appear to have succeeded in stemming deforestation in the Palahurco watershed. In 2000, prior to the initiation of PES, 198 hectares, equivalent to 31 percent of the watershed, had been cleared for cropland and pasture. Since then, agricultural land use has fallen to 88 hectares, or 14 percent, with a corresponding increase in the area reverting to natural vegetation (A. 
Guerrero, personal communication, 2005). In addition, timber extraction has all but ceased. These changes contrast markedly with the continuing deforestation that has occurred during the same period in neighboring areas with similar road access and patterns of settlement. Yet to be studied, hydrologic impacts probably have been less pronounced than changes in land use, given that it takes time for watershed functions to recover after soils have been disturbed. But at the very least, the threat of continued degradation has been largely contained (Wunder and Albán, forthcoming).

The Nueva América Cooperative's acceptance of conservation payments, not to mention the impacts of these payments on resource use, might seem anomalous, in particular since monthly compensation of US\$0.50 to US\$1.00 per hectare is well below the opportunity cost of land (Wunder and Albán, forthcoming). However, individuals are paid for all of their holdings covered by natural vegetation, even though they are capable of clearing only a small share of these holdings in any given year. The opportunity cost of conservation clearly does not amount to US\$0.50 or US\$1.00 per hectare, but instead is much higher. In a financial analysis, Quintero et al. (2006) found that a household with modest land-clearing capacity and a high discount rate gains by accepting the conservation payment. Interviews with members of the Nueva América Cooperative confirm that household spending has increased thanks to PES (Echavarría et al., 2002).

Two caveats must be kept in mind when evaluating watershed services in Palahurco. The first is that, since 2000, Ecuador's liberalization of meat imports has reduced the profitability of ranching, and therefore diminished the rewards of carving new pastures out of forests. In other words, counter-factual (i.e., without-PES) deforestation pressures were reduced. The second caveat, which further complicates definition of the counter-factual scenario, has to do with the effective legal status of forests. To be specific, municipal enforcement of legal prohibitions on logging and landclearing in the Palahurco watershed, which were promulgated during the 1990s, tightened considerably about the time PES was adopted.

While the value of watershed services might be exaggerated if these two caveats are ignored, there are other environmental benefits that have yet to be analyzed. Among these benefits are biodiversity values, which are appreciable since the Palahurco watershed is part of the buffer zone for the Cayambe-Coca Ecological Reserve - one of the most species-rich protected areas in the world.

The Pimampiro initiative is worthy of the attention it has received because it is one of the few, unambiguous examples of PES, with all five features of this approach in place. There are genuine buyers and sellers of a well-defined (and valid) proxy for an environmental service. Participation is voluntary for both groups. Furthermore, conservation payments are truly conditional. Pimampiro has been a widely disseminated model for small-scale, self-organized watershed PES. For instance, CEDERENA is currently replicating the scheme in Loja province, in the southern Ecuador. A similar initiative in Los Negros (Santa Cruz Department, Bolivia) modeled voluntary agreements to halt upstream deforestation on the contract developed for Pimampiro (Asquith et al., forthcoming). What has been put in place in this small, Ecuadorian town thus demonstrates that that it is possible to implement PES in the way economic theorists have devised, at manageable transaction costs and achieving successful and sustainable outcomes. The Pimampiro model is likely to be particularly attractive to other communities searching for novel solutions to difficult watershed problems. 


\section{CASE STUDY 2 \\ FONDO PARA LA CONSERVACION DE AGUA (FONAG), QUITO, ECUADOR}

Perhaps because of its small size and certainly because front-end transaction costs were covered entirely by external donors, Pimampiro was able to institute full-fledged PES very rapidly. In contrast, implementation of this approach for the benefit of Ecuador's national capital has been gradual. Indeed, the process is still unfolding in spite of its having gotten underway a decade ago.

Though PES implementation is not yet complete, water supply has changed a lot in Quito during the past 20 years. As of the late 1980s, households served by the municipal company, EMAAP-Q, suffered multiple difficulties, including frequent interruptions and low water pressure. Moreover, 35 percent of the metropolitan population, mainly in suburban slums, received no service whatsoever from EMAAP-Q and relied instead on water delivered by tanker trucks, at a high cost (Southgate and Figueroa, 2006). These problems had much to do with prices that public authorities had set well below the expense of delivering water to households and other customers. EMAAP-Q's shaky finances, which were a direct outcome of subsidized pricing, also preempted serious efforts to protect water sources and to deal with pollution.

As the Papallacta Project - which increased metropolitan water supplies by 3 cubic meters per second at a capital cost of US\$133 million (Southgate and Whitaker, 1994, pp. 72-73) - was coming on line in 1991, EMAAP-Q was starting to solve interrelated problems of subsidies, unreliable supplies, and entire neighborhoods deprived of service. Cost-recovery improved substantially; by 1995, revenues from water sales were nearly in line with combined expenditures on building, operating, and maintaining pipes, pumping stations, and other infrastructure. Customers accepted price increases without protest because the company used extra funds to improve the quality and reliability of water supplies. In addition, EMAAP-Q's improved financial standing allowed it to extend service to impoverished neighborhoods; by the late 1990s, the share of the metropolitan population lacking a connection to the municipal system had fallen to 10 percent (Southgate and Figueroa, 2006).

The stage was also set to begin dealing with pressing environmental issues. To help build public consensus, The Nature Conservancy (TNC) and its local partners released a widely distributed report - "Water, We Can Take Care of It!” - in 1997 (Krchnak, 2007). The discussion that ensued, which involved EMAAP-Q, the municipal government, and other stakeholders, as well as evidence provided by the local electricity company that stream-flow was declining due to poor watershed management culminated in early 2000 in the establishment of the Fund for the Conservation of Water (FONAG). This fideicomiso was financed mainly by EMAAP-Q, which contributed 1 percent of its sales revenues, approximately equal to US\$360,000 per annum. Additional monies were provided by the electricity company, a private brewery, and the Swiss Agency for Development and Cooperation (Krchnak, 2007).

FONAG's returns are to be used for activities such as the acquisition of land, the control of fires, fencing and other protection for springs, forest conservation, and the promotion of sustainable agriculture as well as monitoring and evaluation of projects. At the end of 2004, FONAG’s balance was US\$2,125,000 and, between interest earnings 
and other income, US\$425,000 were available in 2005. In addition, counterpart funding of US\$560,000 was attracted, which brought the overall budget for the year to $\$ 985,000$ (R. Troya, personal communication, April 2007).

In a complete sense, FONAG does not constitute PES. To date, there have been no direct payments to private providers of environmental services. Obviously, conditionality is not an issue. Instead, payments from users of watershed services are being directed to conventional conservation projects.

The decision to set up a trust fund, rather than channeling current payments from EMAAP-Q's customers directly to field activities, delayed FONAG's impacts for a few years, which prompted complaints in some quarters. However, the financial soundness of this approach has helped to attract counterpart monies, including from TNC (Krchnak, 2007). Furthermore, the endowment continues to grow, with the balance in December 2007 expected to be nearly US\$5.0 million (R. Troya, personal communication, April 2007). As this growth happens, budgets for field activities will be augmented, which ought to enhance FONAG's profile and public support.

Finally, conclusive proof that FONAG's political footing is very sound is that the commitment EMAAP-Q made in 2000 to provide financial support recently became governmental policy. To be specific, Metropolitan Ordinance 0199, enacted on 2 March 2007, mandates that the share of the company's sales revenues will rise from the current level of 1 percent to 4 percent four years from now. Clearly, the buyer's side of PES is firmly established in Quito. 


\section{CASE STUDY 3 PAYMENTS FOR HYDROLOGIC-ENVIRONMENTAL SERVICES- MEXICO}

Pimampiro has been a small-scale experiment with PES. FONAG benefits a much larger population, yet addresses resource use and management in a single drainage basin. In contrast, Mexico’s Program for Hydrologic-Environmental Services (PSA-H), which was instituted in 2003 by the Ministry of the Environment and the National Forestry Commission (CONAFOR), has national coverage - the only initiative of its kind in Latin America besides the PSA Program in Costa Rica.

Whereas the latter encompasses four environmental goods and services - water, carbon, biodiversity, and scenic beauty - the PSA-H focuses on the conservation of threatened natural forests for the sake of maintaining the flow and quality of water. This emphasis reflects mounting water scarcity in Mexico as well as elevated deforestation in many parts of the country (Muñoz-Piña et al., forthcoming).

\section{Payments for Environmental Services Program - Costa Rica}

Costa Rica, where cumulative deforestation is very advanced, pioneered the use of conservation payments in developing countries by establishing its Payments for Environmental Services (PSA) Program in 1997. Forest Law 7575 (1996) established four primary purposes for the Program: (1) mitigation of greenhouse gas emissions; (2) hydrologic services, including provision of water for human consumption, irrigation, and energy production; (3) biodiversity conservation; and (4) protection of scenic beauty for recreation and ecotourism. The same law established a regulatory framework for contracting with landowners for the provision of these services. It also established the semi-autonomous National Fund for Forest Financing (FONAFIFO) to manage the PSA.

To participate in the PSA Program, landowners submit a plan for sustainable forest management, prepared by a licensed forester. Once this plan is approved, specified practices (i.e. timber plantation, forest conservation or forest management) must be adopted, which triggers payments. In 2006, for example, annual payments for forest conservation averaged US\$64/hectare. For forest plantations, approximately US\$816/hectare are disbursed over a 10-year period. Recently, payments for agroforestry were added. Although an initial disbursement can be requested upon contract signing, all subsequent annual payments require verification of compliance.

To date, the PSA Program has been funded primarily with revenues from a national tax on fossil fuels, which averages about US\$10 million per annum. Additional support has included two grants from the Global Environment Facility, a World Bank loan, and a grant from the German aid agency, KFW. In 2005, a new water tariff came into effect, which increased PSA revenues. In addition, new opportunities will be created as global carbon markets continue to develop.

The area enrolled in the PSA Program in late 2005 represented about 10 percent of the country's forests. The effects of payments on deforestation are difficult to pinpoint. Deforestation had leveled off during the early 1990s, prior to the Program's beginnings. An important reason was a decline in the cattle economy, which previously had accounted for most encroachment on treecovered land. Almost certainly, the Program has affected land use since 1997, although existing data and a lack of monitoring make precise quantification impossible.

Regardless, the PSA Program is very popular with landowners, with requests to participate far outstripping available financing. Partly because it is built on previous forest subsidy schemes, it makes relatively uniform payments (fixed rates for each land-use category) and has a low degree of spatial targeting. One important finding from the Costa Rican program is the need to remain flexible and to adapt to lessons learned and changing circumstances, including differentiating payments and focusing efficiency.

Sources: Pagiola (forthcoming); Wünscher et al., (2006). 
Funding for the PSA-H, which grew from US\$18 million in 2003 to US\$30 million in 2004, derives from charges paid by federal water users. Consistent with the Program's basic purpose, monies are disbursed to individual and collective (ejido) landowners possessing natural forests that serve watershed functions. A departure from the Costa Rican scheme, which features uniform levels of per-hectare reimbursement, is that payments for cloud forests (US\$40/hectare/year) exceed those for other tree-covered land (US\$30/hectare/year). This differentiation reflects the value of capturing horizontal precipitation in the former habitat.

As in Costa Rica, contracts with suppliers of environmental services are for five years, with conditional renewal. Payments are made at year's end in cash, provided that compliance with contractual obligations has been satisfactory during the preceding twelve months. Compliance-monitoring is the responsibility of CONAFOR, which analyzes satellite imagery and carries out random and occasional field visits to detect changes from forest-cover baselines. If some but not all of a landowner's holdings are deforested due to the action of a third party (e.g., forest fires), then payments for that subarea come to an end. But a landowner who deliberately clears any part of his enrolled holdings, to make way for new cropland or pastures for example, then the contract is rendered null and void and all payments cease.

The response of Mexican landowners to the program has been strong. The 2003 budget allowed for the enrollment of 126,000 hectares, although offers were received for 560,000 hectares (Bayon, 2004). In response to the gap between the budgeted area and applications, CONAFOR has worked with the National Water Commission (CNA) to identify forests that are important in terms of watershed protection or aquifer recharge and that are upstream from at least 5,000 water consumers. Prioritization also takes into account natural forests of good quality where commercial logging is not viable as well as biodiversity (e.g., the protection of unique habitats in mountainous settings). In addition, areas where the threat of deforestation is great, based on econometric analysis carried out by the Instituto Nacional de Ecología (INE), are supposed to be given high priority, as are zones with an elevated incidence of poverty.

Relative weights assigned to these criteria have changed during the four years of PSA-H's existence. For example, the Program at times has had to satisfy different interest groups by giving more or less importance to poverty alleviation or biodiversity protection. All else remaining the same, this affects potential watershed benefits. Moreover, experience has allowed the spatial targeting of PES to improve over time (Muñoz-Piña et al., forthcoming). As indicated in Figure 3, the PSA-H has become much better at concentrating enrollment in the vicinity of over-exploited aquifers and somewhat better at addressing the needs of municipalities facing acute water scarcity. In addition, emphasis on marginalized areas where poverty alleviation is an important objective has increased. A more worrying trend is that conservation payments are now being directed less to places with the greatest deforestation risk. In 2006, for example, forests placed in the bottom quintile in terms of this risk were 43 percent over-represented in the group selected to receive conservation payments - up from 22 percent in 2004. The same year, just 6 percent of the forested tracts identified in the top quintile were enrolled, down from 11 percent in 2004 (Muñoz-Piña et al., forthcoming; C. Muñoz-Piña, personal communication, January 2007). 
In part, these changes have to do with CONAFOR's original decision to focus on areas with low deforestation risk but with an elevated incidence of poverty. Obviously, landowners have an incentive to offer areas with modest (or even negative) opportunity costs to the PSA-H. As a bottom line, the PSA-H's overall service additionality, defined as the service-level potential times the probability of having an impact on land use, may actually have decreased over time, due to a greater inclusion of little or no risk of deforestation. The eventual effects on the quality and availability of water are difficult to estimate, since little hydrologic monitoring has been undertaken.

\section{Figure 3: Evolving Emphases of the Mexican PSA-H}

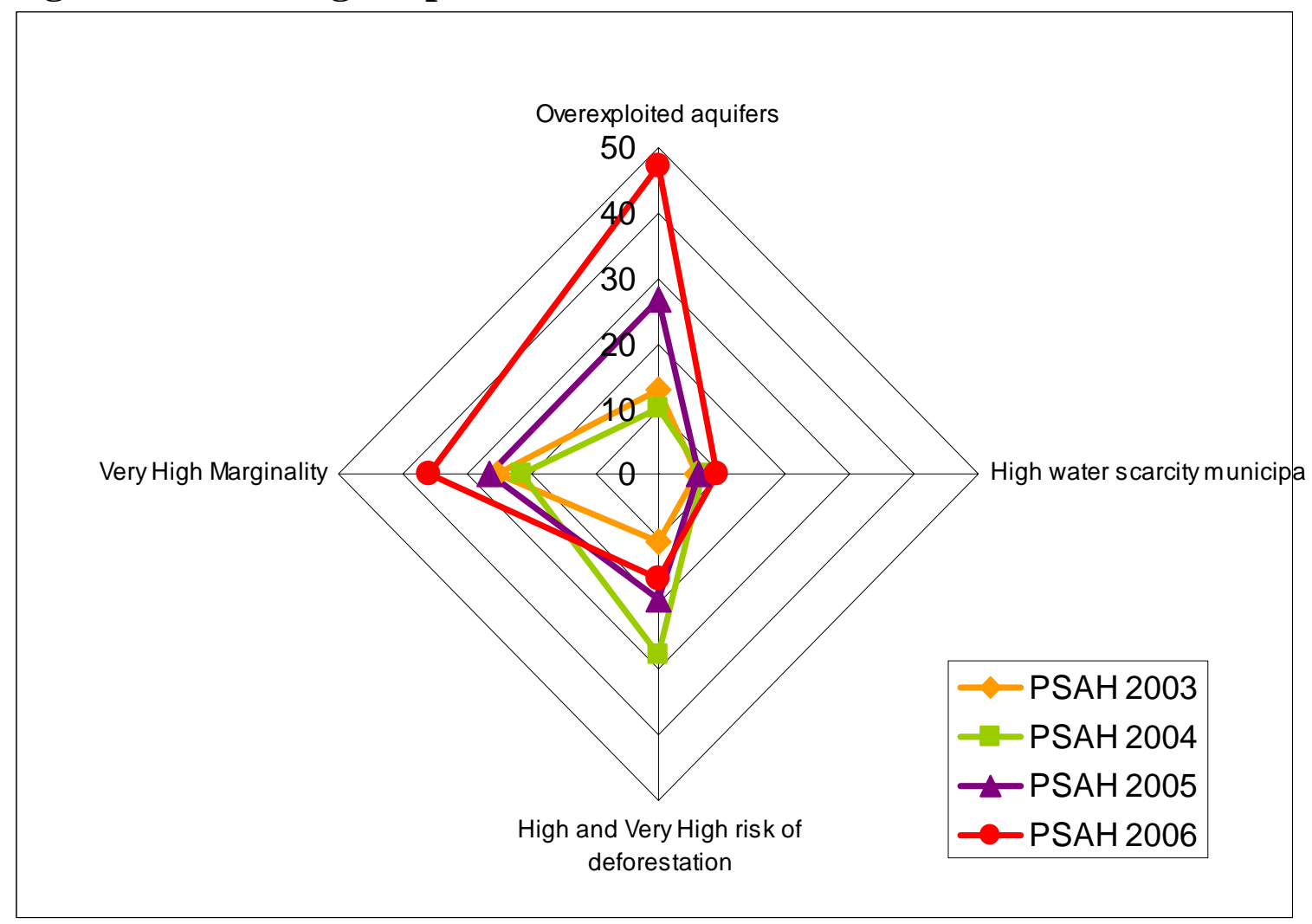

With respect to poverty alleviation, targeting places with high natural-forest cover is in itself a powerful pro-poor filter, since no less than two-thirds of these places are categorized as having a very high incidence of poverty. In 2003, 93 percent of enrolled areas were in ejidos and other rural communities (Alix-García et al., 2005), although within this group the poorest households were not as likely to participate as their neighbors. In 2006, 72 to 83 percent of PSA-H payments went to forests in settings characterized by high or very high poverty. In 2004, an INE survey showed that 31\% of PSA-H beneficiaries had incomes below the poverty line, although the poorest of the poor were under-represented among payment-recipients. For impoverished households, PSA participation could raise incomes by up to $10 \%$ (Muñoz-Piña et al., forthcoming). For community-owned forests, PSA-H payments were often utilized to invest in villagelevel infrastructure (Alix-García et al., 2005).

With respect to sustainability of the scheme, the PSA-H is intended only to provide a temporary incentive for conservation in any given setting. The intention is for 
a transition to occur in all enrolled areas either to self-sustaining commercial forestry or to conservation paid for by direct beneficiaries within the watershed. The former sort of transition may often be unrealistic. For a transition to be made to locally financed conservation - that is, to full-fledged, local PES - the Program's environmental services will have to be evaluated, in order to interest local buyers of these services.

What lessons has the Mexican PSA-H program provided so far? Compared to the Costa Rican system, it is more sophisticated in terms of targeting tools, which in principle gives it the potential to achieve more additionality. However, application of these tools so far has been heavily constrained by side-objective prioritization and political-economy obstacles to implementation, which is seemingly a quite common feature for nationallevel PES schemes. In addition, the program has experienced multiple changes between the design and implementation phases (Muñoz-Piña et al., forthcoming; Alix-García et al.,2005).

Recurrent transaction costs of the PSA-H have legally been limited to 4 percent of total transfers (not counting additional operational expenditures charged to the budget of the federal agency which implements the program), which means that cost shares are probably lower than in Costa Rica. This might indicate efficient administrative design, including the capture of scale economies. Nevertheless, low transaction costs seem at least in part to come at the cost of weaknesses in monitoring. In one region, Sierra Gorda Biosphere Reserve, it is reported that there is no effective control of over-grazing of enrolled forests, since in the short run canopy cover is not reduced; however, overgrazing for sustained periods degrades forests and compacts soils, thereby diminishing hydrologic functions (Bayon, 2004). Even CONAFOR's monitoring of land-use changes with satellite imagery recently has been proved superficial (C. Muñoz-Piña, personal communication, January 2007). There also has been some rent-seeking by communities engaged in commercial timber operations, which contrary to the original intentions of the PSA-H have enrolled their holdings and continue to receive payments due to gaps in monitoring.

In addition, some of the currently contracted conservation areas may be too fragmented over multiple watersheds to have significant hydrologic impacts (Alix-García et al., 2005). To date, the overall benefits of PSA-H implementation for water consumers may thus be less significant than those received by poor service providers. Weaknesses in monitoring and the failure to focus on genuinely threatened areas are key issues to be addressed. As an underlying factor of accountability, a forestry institution like CONAFOR may not be the best representative of water consumers. The latter may need to be more directly involved in PSA-H implementation to ensure the desired hydrologic outcomes that, after all, constitute the Program's raison d'être. 


\section{REFERENCES}

Albán, M. and M. Argüello. 2004. "Un Análisis de los Impactos Sociales y Económicos de los Proyectos de Fijación de Carbono en el Ecuador: El Caso de PROFAFOR-FACE," Mercados para Servicios Ambientales, \#7, 74, International Institute for Environment and Development, London.

Alix-García, J., A. de Janvry, E. Sadoulet, and J. M. Torres. 2005. "An Assessment of Mexico's Payment for Environmental Services Program," Rome.

Asquith, N., M.T. Vargas-Ríos, and J. Smith. 2002. "Can Forest-Protection Carbon Projects Improve Rural Livelihoods? Analysis of the Noel Kempff Mercado Climate Action Project, Bolivia," Mitigation and Adaptation Strategies for Global Change, 7, pp. 323-37.

Asquith, N., M.T. Vargas-Ríos, and S. Wunder. Forthcoming. "Building Environmental Services, Decentralized In-Kind Payments for Bird Habitat, and Watershed Protection in Los Negros, Bolivia," Ecological Economics.

Bayon, R. 2004. "Case Study: The Mexico Forest Fund,” in the Katoomba Group's Ecosystem Marketplace. http://ecosystemmarketplace.com/pages/article.news. php? component_id=2049\&component_version_id=6441\&language id=12

Blanco, J. with S. Wunder, and F. Navarrete. 2005. "La Experiencia Colombiana en Esquemas de Pagos por Servicios Ambientales," Ecoversa \& CIFOR, Bogotá. http://www.cifor.cgiar.org/pes/publications/pdf files/colombia_experience.pdf

Blanco, J. with S. Wunder, and S. Sabogal. 2006. "Potencialidades de Implementación de Esquemas de Pagos por Servicios Ambientales en Venezuela." Ecoversa \& CIFOR: Bogotá. http://www.cifor.cgiar.org/pes/publications/pdf_files/CIFOR-Ecoversa.pdf

CEDERENA. 2002. "Pago por Servicios Ambientales: La Experiencia de la Asociación Nueva América" CEDERENA and Interamerican Foundation, DFC-FAO, Ibarra.

Chomitz, K.M. and K. Kumari. 1998. "The Domestic Benefits of Tropical Forests: A Critical Review,” World Bank Research Review, 13.

Corral, M.A. and F. Rodríguez. 2006. "Diagnóstico del Estado Legal Existente para el Establecimiento de Programas de Pago por Servicios Ambientales,” Fundación Antisana, Quito.

Echavarría, M., J. Vogel, M. Albán, and F. Meneses. 2002. "The Impacts of Payments for Watershed Services in Ecuador," International Institute for Environment and Development, London.

Ferraro, P.J. 2001. "Global Habitat Protection: Limitations of Development Interventions and a Role for Conservation Performance Payments," Conservation Biology, 15, pp. 990-1000.

Ferraro, P.J. and A. Kiss. 2002. "Direct Payments for Biodiversity Conservation,” Science, 298, pp. 17181719.

Ferraro, P.J. and R.D. Simpson. 2002. “The Cost-Effectiveness of Conservation Performance Payments,” Land Economics, 28, pp. 339-353.

González-Vega, C., J. Rodríguez-Meza, D. Southgate, and J. Maldonado. 2004. “Poverty, Structural Transformation, and Land Use in El Salvador,” American Journal of Agricultural Economics, 86, pp. 13671374.

Grieg-Gran, M., I.T. Porras, and S. Wunder. 2005. "How Can Market Mechanisms for Forest Environmental Services Help the Poor? Preliminary Lessons from Latin America," World Development, 33, pp. 15111127.

Hamilton, L. and P. King. 1983. Tropical Forested Watersheds: Hydrologic and Soils Responses to Major Uses or Conversions. Boulder: Westview Press.

Hardner, J. and R. Rice. 2002. "Rethinking Green Consumerism," Scientific American, May, pp. 89-95.

Hausmann, R., D. Rodrik, and A. Velasco. 2005. "Growth Diagnostics” (mimeo), John F. Kennedy School of Government, Harvard University, Cambridge.

Kagel, J. 1995. “Auctions: A Survey of Experimental Research,” in J. Kagel and A. Roth (eds.), Handbook of Experimental Economics. Princeton: Princeton University Press.

Krchnak, K. 2007. "Watershed Valuation as a Tool for Biodiversity Conservation” (report to U.S. Agency for International Development), The Nature Conservancy, Arlington.

Landell-Mills, N. and I. Porras. 2002. Silver Bullet or Fool's Gold? A Global Review of Markets for Forest Environmental Services and Their Impact on the Poor. London: International Institute for Environment and Development. 
May, P.H., F. Veiga Neto, V. Denardin, and W. Loureiro. 2002. "Using Fiscal Instruments to Encourage Conservation: Municipal Responses to the 'Ecological' Value-Added Tax in Paraná and Minas Gerais, Brazil," in S. Pagiola, J. Bishop, and N. Landell-Mills (eds.), Selling Forest Environmental Services: Market-Based Mechanisms for Conservation and Development. London: Earthscan.

May, P., E. Boyd, F. Veiga, and M. Chang. 2004. "Local Sustainable Development Effects of Forest Carbon Projects in Brazil and Bolivia: A View from the Field" 143, International Institute for Environment and Development, London.

Muñoz-Piña, C., A. Guevara, J. M. Torres, and J. Braña. Forthcoming. "Paying for the Hydrological Services of Mexico's Forests: Analysis, Negotiation, and Results,” Ecological Economics.

Pagiola, S. 2002. "Paying for water services in Central America: Learning from Costa Rica,” in S. Pagiola, J. Bishop, and N. Landell-Mills (eds.), Selling Forest Environmental Services: Market-Based Mechanisms for Conservation and Development. London: Earthscan.

Pagiola, S. Forthcoming. "Payments for Environmental Services in Costa Rica,” Ecological Economics.

Quintero, M., R. D. Estrada, N. Uribe, and M. Martínez. 2006. "Análisis Hidrológico y Económico Enfocado hacia el Pago por Servicios Ambientales: La Microcuenca del Río Palaurco (Ecuador)” (informe para CIFOR), CIAT, Palmiras.

Rice, R.E., C.A. Sugal, S.M. Ratay, G.A.V. da Fonseca. 2001. "Sustainable Forest Management: A Review of Conventional Wisdom," Center for Applied Biodiversity Science, Conservation International, Washington.

Robertson, N. and S. Wunder. 2005. "Fresh Tracks in the Forest: Assessing Incipient Payments for Environmental Services Initiatives in Bolivia,” Center for International Forestry Research, Bogor.

Rodríguez-Meza, J., D. Southgate, and C. González-Vega. 2004. "Rural Poverty, Household Responses to Shocks, and Agricultural Land Use: Panel Results for El Salvador,” Environment and Development Economics, 9, pp. 225-239.

Rodrik, D. 2006. "Goodbye Washington Consensus, Hello Washington Confusion? A Review of the World Bank’s Economic Growth in the 1990s: Learning from a Decade of Reform,” Journal of Economic Literature, 44, pp. 973-987.

Simpson, R.D. and R.A. Sedjo. 1996. "Paying for the Conservation of Endangered Ecosystems,” Environment and Development Economics, 1, pp. 241-257.

Southgate, D. and E. Figueroa. 2006. "Reforming Water Policies in Latin America: Some Lessons from Chile and Ecuador, in K. Okonski (ed.), The Water Revolution: Practical Solutions to Water Scarcity. London: International Policy Press.

Southgate, D., T. Haab, and F. Rodríguez. 2005. "Payments to the Rural Poor for the Sake of Conserving Tropical Watersheds: A Contingent Valuation Analysis in Ecuador," presented at annual meeting of the Association of Environmental and Resource Economists, Providence.

Southgate, D. and R. Macke. 1989. "The Downstream Benefits of Soil Conservation in Third World Hydroelectric Watersheds," Land Economics, 65, pp. 38-48.

Southgate, D. and M. Whitaker. 1994. Economic Progress and the Environment: One Developing Country's Policy Crisis. New York: Oxford University Press.

Veen, M. 2007. "Oportunidades para Pago por Servicios Ambientales en la Amazonía Peruana: Diagnóstico Rápido," 20, Dutch Service for Development Cooperation (SNV), La Paz.

Wunder, S. 2007. "The Efficiency of Payments for Environmental Services in Tropical Conservation," Conservation Biology, 21, pp. 48-58.

Wunder, S. and M. Albán. Forthcoming. "Decentralized Payments for Environmental Services: Comparing the Cases of Pimampiro and PROFAFOR in Ecuador," Ecological Economics.

Wunder, S., B.D. The, E. and Ibarra. 2005. "Payment is Good, Control is Better: Why Payments for Environmental Services So Far Have Remained Incipient in Vietnam," CIFOR, Bogor.

Wünscher, T., S. Engel, and S. Wunder. 2006. "Payments for Environmental Services in Costa Rica: Increasing Efficiency through Spatial Differentiation," Quarterly Journal of International Agriculture, 45, pp. 317-35. 


\section{ANNEX}

\section{ALLEVED WATERSHED PES SCHEMES}

A. SOUTH AMERICAN PROJECTS

\begin{tabular}{|c|c|c|c|}
\hline Country & Sources** & Initiative & Status informed in source \\
\hline Bolivia & 1,2 & Bermejo (area shared with Argentina) & Abandoned or discontinued \\
\hline Bolivia & 2 & Comarapa Municipality & No detailed information \\
\hline Bolivia & 2,3 & ICO, Sta. Cruz Department & Ongoing \\
\hline Bolivia & 2,3 & Los Negros & Ongoing \\
\hline Bolivia & 2 & San Pedro (GTZ) & Advanced proposal \\
\hline Bolivia & 2 & Sucre (GTZ) & Advanced proposal \\
\hline Bolivia & 1,3 & Tarija - PROMETA, Sama Reserve & Ongoing \\
\hline Bolivia & 2 & Watershed management programme (GTZ) & Advanced proposal \\
\hline Brazil & 2 & CPCJ riverban restoration & Ongoing \\
\hline Brazil & 2 & Proambiente (Amazon basin) & Ongoing \\
\hline Brazil & $1,2,10$ & ICMS municipal tax incentives & Ongoing \\
\hline Brazil & 2 & São João Watershed (WWF) & No detailed information \\
\hline Brazil & 1 & SEMAE, São Paulo & None \\
\hline Brazil & 7 & Semi-Arid Sertão GEF project & Advanced proposal \\
\hline Chile & 1 & Water share trading & Abandoned or discontinued \\
\hline Colombia & 2 & Afluentes del Cauca & Advanced proposal \\
\hline Colombia & 1 & Campoalegre user association & Ongoing \\
\hline Colombia & 2 & Fúquene Lake & Ongoing \\
\hline Colombia & 2 & La Miel HEP & Advanced proposal \\
\hline Colombia & 2,10 & CIPAV silvopasture LA Vieja & Advanced proposal \\
\hline Colombia & 1,10 & Valle del Cauca irrigator payments & Ongoing \\
\hline Colombia & 10 & Chaina water user payments & Ongoing \\
\hline Colombia & 1,4 & CIF national watershed scheme & Abandoned or discontinued \\
\hline Colombia & 10 & Santander \& Boyacá Corridor Natura & Ongoing \\
\hline Colombia & 8 & Guabas River irrigator payments & Ongoing \\
\hline Ecuador & 2,10 & Ambato & Advanced proposal \\
\hline Ecuador & 2 & Arenillas & No detailed information \\
\hline Ecuador & 2 & Cotacachi, Imbabura & No detailed information \\
\hline Ecuador & $1,2,10$ & Cuenca water user payments & Ongoing \\
\hline Ecuador & 2 & EcoFondo Podocarpus National Park & Advanced proposal \\
\hline Ecuador & $1,2,10$ & FONAG, Quito & Ongoing \\
\hline Ecuador & 9 & El Chaco water users, CEDERENA & Ongoing \\
\hline Ecuador & 2 & Pedro Moncayo & Ongoing \\
\hline Ecuador & 2,10 & Pimampiro & Ongoing \\
\hline Ecuador & 2,10 & El Angel & Advanced proposal \\
\hline Ecuador & 10 & Celica, Loja - CEDERENA & Advanced proposal \\
\hline Ecuador & 10 & Paute HEP - Nudo de Azuay conservation & Advanced proposal \\
\hline Ecuador & 2 & Shutan Bajo & Ongoing \\
\hline Peru & 5 & Alto Mayo (Cuencas Andinas) & Advanced proposal \\
\hline Peru & 5 & Arequipa (Cuencas Andinas) & Advanced proposal \\
\hline Peru & 5 & Jequetepeque (Cuencas Andinas) & Advanced proposal \\
\hline Peru & 2,5 & Piura (Cuencas Andinas) & Advanced proposal \\
\hline Venezuela & 2 & Partnerships for National Parks & Advanced proposal \\
\hline Venezuela & 6 & Pereño/ La Jabonosa rivers, Táchira & Ongoing \\
\hline Venezuela & 7 & Venezuelan Andes Project, GEF & Advanced proposal \\
\hline Venezuela & 7 & Guri HEP payments to Canaima NP & Ongoing \\
\hline
\end{tabular}




\section{B. MESO AMERICAN AND CARIBBEAN PROJECTS}

\begin{tabular}{|c|c|c|c|}
\hline Country & Sources** & Initiative & Status informed in source \\
\hline Costa Rica & 2 & State Power producer (CNFL) & Ongoing \\
\hline Costa Rica & 2 & Del Oro farmer payments & Abandoned or discontinued \\
\hline Costa Rica & 1,2 & Energia Global, Central Plateau & Ongoing \\
\hline Costa Rica & 2 & ICE (National Institute of Electricity) & Ongoing \\
\hline Costa Rica & 1,2 & ICE-Arenal Watershed Fund & Abandoned or discontinued \\
\hline Costa Rica & 2 & La Esperanza & Ongoing \\
\hline Costa Rica & 2 & La Florida & Ongoing \\
\hline Costa Rica & 1,2 & Platanar River, San Carlos & Ongoing \\
\hline Costa Rica & 1,2 & San José Watershed Fund & Abandoned or discontinued \\
\hline Costa Rica & 1,2 & Heredia Public Service Enterprise & Ongoing \\
\hline Costa Rica & 1 & Monteverde Cloud Forests & None \\
\hline Costa Rica & 1,2 & PSA National Program & Ongoing \\
\hline Costa Rica & 1 & $\begin{array}{l}\text { Norwegian purchase of carbon offsets and Costa } \\
\text { Rican Power Company's purchase of improved water } \\
\text { quality }\end{array}$ & Ongoing \\
\hline $\begin{array}{l}\text { Dominican } \\
\text { Republic }\end{array}$ & 2 & PROCARYN pooled water resource conservation & Advanced proposal \\
\hline $\begin{array}{l}\text { Dominican } \\
\text { Republic }\end{array}$ & 7 & Upper Sábana Yegua, GEF & Advanced proposal \\
\hline El Salvador & 2 & Jaltepeque-Jiquilisco & Ongoing \\
\hline El Salvador & 2 & Coatepeque & Ongoing \\
\hline El Salvador & 7,10 & Ecoservicios (national program) & Abandoned or discontinued \\
\hline El Salvador & 1 & El Imposible National Park & Ongoing \\
\hline El Salvador & 2 & PASOLAC & Ongoing \\
\hline Guatemala & 2 & Cerro San Gil & Ongoing \\
\hline Guatemala & 1 & Montagua River, Sierra de Las Minas & Advanced proposal \\
\hline Guatemala & 2 & MAGA national scheme & Ongoing \\
\hline Guatemala & 2 & San Jerônimo (GTZ) & Ongoing \\
\hline Honduras & 2 & Campamento, Olancho & Ongoing \\
\hline Honduras & 2,8 & Sta Bárbara - El Escondido, Copán & Advanced proposal \\
\hline Honduras & 2 & Jesus de Otoro & Ongoing \\
\hline Honduras & 2 & Orica Creek (WWF/CARE/IIED) & Advanced proposal \\
\hline Honduras & 2 & Rio Platano (GTZ) & Advanced proposal \\
\hline Jamaica & 2 & Buff Bay & Advanced proposal \\
\hline Jamaica & 1 & Watershed protection contracts and fees & Uncertain \\
\hline Mexico & 2 & Copalita & None \\
\hline Mexico & 8 & Lerma Chapala Basin & Pilot \\
\hline Mexico & 8 & Triunfo Biosphere Reserve Chiapas & Pilot \\
\hline Mexico & 8 & Coatepec, Veracruz & Proposed \\
\hline Mexico & 2 & Fideicoagua & Ongoing \\
\hline Mexico & 2 & National PSAH & Ongoing \\
\hline Mexico & 2 & Pronatura & None \\
\hline Mexico & 2 & Valle de Bravo & Ongoing \\
\hline Mexico & 2 & Zapaliname & Ongoing \\
\hline Nicaragua & 2 & San Pedro Norte & Ongoing \\
\hline Panama & $1,2,10$ & Panama Canal watershed reforestation & Advanced proposal \\
\hline Panama & 7 & 2nd Mesoamerican Corridor Project, GEF & Advanced proposal \\
\hline Panama & 2 & Fito del Tallo hills, Darien & No detailed information \\
\hline St Lucia & 2 & Talvem Watershed & Advanced proposal \\
\hline
\end{tabular}




\section{** Sources}

1. Landell-Mills, N. and I. Porras. 2002. Silver Bullet or Fool's Gold? A Global Review of Markets for Forest Environmental Services and Their Impact on the Poor. London: International Institute for Environment and Development.

2. Ina Porras and Nanette Neves, personal communication, September 2007.

3. Robertson, N. and S. Wunder. 2005. "Fresh Tracks in the Forest: Assessing Incipient Payments for Environmental Services Initiatives in Bolivia,” Center for International Forestry Research, Bogor.

4. Blanco, J. with S. Wunder, and F. Navarrete. 2005. "La Experiencia Colombiana en Esquemas de Pagos por Servicios Ambientales," Ecoversa \& CIFOR, Bogotá. http://www.cifor.cgiar.org/pes/publications/pdf_files/colombia_experience.pdf

5. Veen, M. 2007. "Oportunidades para Pago por Servicios Ambientales en la Amazonía Peruana: Diagnóstico Rápido," 20, Dutch Service for Development Cooperation (SNV), La Paz.

6. Blanco, J. with S. Wunder, and S. Sabogal. 2006. "Potencialidades de Implementación de esquemas de pagos por servicios ambientales en Venezuela." Ecoversa \& CIFOR: Bogotá. http://www.cifor.cgiar.org/pes/publications/pdf files/CIFOR-Ecoversa.pdf

7. Gutman, P. and S. Davidson. 2006. "A Review of the GEF Payment for Environmental Services (PES) Portfolio and Recommendations on the Potential Role for PES in Future GEF and FAO Programs," World Wildlife Fund, Washington.

8. Mayrand, K. and M. Paquin. 2004. "Payments for Environmental Services: A Survey and Assessment of Current Schemes,” Unisféra International Centre, Montreal.

9. Izko, X. and D. Cordero. 2006. "Estrategia Nacional de Financiamiento Forestal: Ecuador,” GTZ, FAO, and IUCN, Quito.

10. Personal observation by Sven Wunder. 